\title{
KINERJA DOSEN DI BIDANG PENELITIAN DAN PUBLIKASI ILMIAH
}

\author{
Trie Hartiti Retnowati ${ }^{1}$, Djemari Mardapi 1, Badrun Kartowagiran 1 * \\ 1Universitas Negeri Yogyakarta \\ 1Jl. Colombo No. 1, Depok, Sleman 55281, Yogyakarta, Indonesia \\ * Corresponding Author. Email: kartowagiran@uny.ac.id
}

\begin{abstract}
Abstrak
Keharusan publikasi ilmiah dari Pemerintah, dapat mendorong dosen untuk meningkatkan kualitas, kuantitas penelitian dan publikasi ilmiah. Sehubungan dengan hal ini, tujuan penelitian ini adalah mengeksplor kinerja dosen di bidang penelitian dan publikasi ilmiah. Informasi ini dapat digunakan oleh stakeholder untuk melakukan pembinaan terhadap kinerja dosen. Penelitian ini merupakan penelitian survei dan untuk mengumpulkan data digunakan kuesioner yang memiliki validitas dan reliabilitas tinggi, dilengkapi dengan teknik observasi. Pada tahap awal, responden penelitian ini adalah 92 dosen Universitas Negeri Yogyakarta yang terdiri dari 22 Asisten ahli, 26 Lektor, 28 Lektor Kepala, dan 16 Profesor. Hasil penelitian menunjukkan bahwa selama tiga tahun terakhir skor kinerja dosen dalam bidang penelitian dan publikasi ilmiah untuk semua kelompok jabatan mengalami peningkatan, tetapi ada perbedaan skor kinerja dosen dalam penelitian dan publikasi ilmiah bila dilihat dari jabatan dosen. Guru Besar menduduki ranking tertinggi, baik untuk skor kinerja dosen dalam penelitian maupun publikasi ilmiah diikuti oleh Lektor Kepala, Lektor, dan Asisten Ahli.

Kata kunci: kinerja dosen, penelitian, publikasi ilmiah
\end{abstract}

\section{LECTURERS' PERFORMANCE IN SCIENTIFIC RESEARCH AND PUBLICATION}

\begin{abstract}
The necessity of scientific publication insisted by the government can encourage lecturers to improve their scientific research and publication, both in quality and quantity. In connection with this fact, this research is aimed at exploring lecturers' performance in terms of scientific research and publication. The information gained through the result of this study can be used by the stakeholder to develop the lecturers' performance. This study is a survey research employing high-validity-and-reliability questionnaire to collect the data, completed with the employment of observation technique. At the initial stage, the respondents of the study were 92 lecturers of Universitas Negeri Yogyakarta consisting of 22 instructors, 26 assistant professors, 28 associate professors, and 16 professors. The results of the study indicate that during the last three years, there is an increase on the total scientific research performance score and publication at every level of the functional position, but there is also a difference the scientific research performance score and publication seen from these functional positions. Professors are at the highest rank of the scientific research performance score and publication, followed by associate professors, assistant professors, and instructors.
\end{abstract}

Keywords: lecturers' performance, scientific research, scientific publication

Permalink/DOI: $h$ ttp://dx.doi.org/10.21831/amp.v6i2.21524 


\section{Pendahuluan}

Ada dua tantangan yang dihadapi Bangsa Indonesia, yakni Era MEA dan revolusi industri 4.0. Pada era Masyarakat Ekonomi Asian (MEA) yang mulai diberlakukan pada 31 Desember 2015 (Chia, 2013) terjadi "single market and production base: free flow of goods, free flow of services, free flow of investment, free flow of capital, free flow of skilled labour, priority integration sector, food, agriculture and foresty". Sementara itu, pada era revolusi industri 4.0 semua mesin dihubungkan dengan yang lain, bertumpu pada cyber physical system yang akan mengubah secara radikal cara manusia berkehidupan, bekerja, dan berkomunikasi. Inovasi yang dihasilkan untuk membuat kehidupan lebih nyaman tidak terbatas, tetapi tantangan yang harus dipecahkan juga sangat kompleks. Pekerjaan yang semula dilakukan manual dengan mengandalkan tenaga manusia semata sudah digantikan oleh mesin dan teknologi informasi.

Teknologi informasi yang ada saat ini mampu menyediakan berbgai informasi, termasuk informasi yang terkait dengan pembelajaran. Hampir semua tugas guru "di-handle" oleh Google dan/atau internet. Bahkan cara berpikir, mulai dari yang rendah sampai yang tingkat tinggi juga disediakan oleh Google dan/atau internet. Fakta ini memberikan sinyal bahwa guru dituntut untuk mampu mengajarkan kognitif tingkat tinggi. Mengajarkan cara berpikir tingkat tinggi hanya dapat dilakukan dengan cara memberi contoh dan ini hanya dapat dilakukan oleh guru yang berkualitas. Terkait dengan hal ini, penelitian Abrami et al. (2008) yang melakukan metaanalisis terhadap 341 penelitian yang menggunakan pendekatan eksperimen dan kuasi eksperimen tentang strategi mengajari siswa untuk berfikir kritis menemukan bahwa memberikan peluang untuk berdialog, membiarkan siswa untuk menghadapi permasalahan-permasalahan, memberikan contoh berfikir kritis, dan memberikan pembinaan pada siswa akan berdampak positif pada keterampilan berpikir kritis.

Guru yang berkualitas tidak hanya mampu menyelenggarakan pendidikan di dalam kelas (pembelajaran), tetapi juga mampu melakukan pendidikan berkualitas di luar kelas. Semakin tinggi kualitas guru, semakin tinggi kualitas pembelajaran, dan pada gilirannya semakin tinggi pula kualitas pendidikan. Hal ini sejalan dengan pendapat Marzano, Frontier, \& Livingston (2011) yang mengatakan bahwa semakin banyak kegiatan positif guru di dalam kelas, semakin tinggi prestasi belajar siswa. Sementara itu, Barber \& Mourshed (2012) mengatakan bahwa prestasi belajar siswa dimulai dari guru dan kepala sekolah yang efektif. Bahkan di bagian lain Barber dan Mourshed menjelaskan bahwa "student placed with high performing teachers will progress three times as fast as those placed with low performing teachers".

Uraian tersebut menggambarkan begitu pentingnya pendidik atau guru atau dosen bagi perguruan tinggi. Kualitas lulusan perguruan tinggi sangat tergantung pada kinerja dosen. Jones, Jenkin, \& Lord (2006, p. 3) dalam buku mereka yang berjudul "Developing Teacher Effective Performance" menuliskan bahwa "Performance means both behaviours and result. Behaviours emanate from the performer and tranform performance from abstraction to action. Not just the instruments for result, behaviours are also outcomes in their own right - the product of mental and physical effort applied to task - and can be judged apart from result". Dalam pengertian ini Jones et al. (2006, p. 4) mengatakan "performance leads to the conclution that an individual's performance needs to be gauged with both behaviours and outcomes in mind". Dalam arti unjuk kerja, kinerja merupakan kumpulan total dari perilaku yang ditunjukkan seseorang pekerja, dengan demikian kinerja dosen adalah hasil yang dicapai oleh dosen dalam melaksanakan tugas yang dibebankan kepadanya dan menjadi tanggung jawab dosen didasarkan kepada kecakapan, pengalaman, dan kesungguhan dalam rentang waktu tertentu.

Kinerja merupakan fungsi dari kemampuan dan motivasi; seseorang yang memiliki kemampuan tinggi tidak akan berkinerja tinggi manakala dia tidak memiliki motivasi tinggi. Hal ini selaras dengan hasil 
penelitian Astuti (2017) yang menemukan bahwa ada pengaruh yang signifikan antara motivasi terhadap kinerja guru SD di Kabupaten Cilacap. Sementara itu, Mugimu, Nakabugo, \& Katunguka (2013) yang mengambil asumsi Teori Sistem Motivasi (MST) mengatakan bahwa pencapaian aktual seseorang itu mengacu pada keterampilan dan motivasi orang tersebut. Selain itu, Ford (1992) menyatakan bahwa motivasi dapat didefinisikan dalam tiga fungsi psikologis yang berfungsi untuk mengarahkan, memberi energi, dan mengatur aktivitas yang diarahkan pada tujuan: sasaran pribadi, proses gairah emosional, dan kepercayaan agen pribadi.

Sementara itu, Berk (1986) menjelaskan cara melakukan penilaian kinerja, yaitu proses mengumpulkan data dengan cara pengamatan yang sistematik untuk membuat keputusan tentang individu. Ada lima aspek utama yang tersirat dan tersurat pada definisi tersebut, yaitu: proses, pengumpulan data, pengamatan sistematik, integrasi data, dan keputusan individu. Selanjutnya Cronbach (1985) menjelaskan bahwa semua tes pada dasarnya adalah untuk mengukur kinerja dalam suatu segi. Penilaian kinerja biasanya digunakan terhadap suatu tugas yang membutuhkan respons nonverbal, misal tes praktik untuk mengajar, melukis, menyanyi, dan melawak. Tes kinerja mengacu pada suatu standar yang ingin dicapai atau yang ditetapkan sebagai batas minimum yang harus bisa dilakukan peserta tes, sehingga standar yang ingin dicapai harus ditetapkan lebih dahulu. Pada penilaian kinerja, seseorang dapat disuruh untuk melakukan respon ganda terhadap suatu pertanyaan sesuai dengan suatu ketetapan tertentu (Yen, 1993). Respons ganda ini merupakan informasi yang dibutuhkan untuk menentukan kinerja seseorang dalam bidang tertentu. Oleh karena itu pada penilaian kinerja, dimensi yang diukur tidak hanya satu, melainkan lebih.

Beberapa hasil penelitian dan peraturan perundang-undangan yang telah dipaparkan di atas menunjukkan bahwa kinerja dosen merupakan faktor utama dalam menjaga kualitas pendidikan. Bila kinerja dosen dapat terjaga dengan baik maka hasil proses pendidikan yang diperoleh tetap berkualitas dengan baik. Dalam rangka mewujudkan kondisi ini diperlukan suatu penilaian yang kontinu terhadap kinerja dosen agar diperoleh informasi yang terkini mengenai kondisi kinerja dosen. Dengan harapan apabila terjadi penurunan kinerja dosen akan segera diketahui dan dapat diberikan tindakan yang tepat. Hal ini sejalan dengan hasil penelitian Peleyeju \& Ojebiyi (2013) yang merekomendasikan bahwa pengelola perguruan tinggi harus menjamin penilaian kinerja dosen secara menyeluruh dan terus menerus dalam rangka meningkatkan kualitas dosen dan kualitas manajemen secara keseluruhan di perguruan tinggi. Lebih ditekankan lagi oleh Bai, Rajput, Hussain, \& Khoja (2014) bahwa evaluasi kinerja dosen merupakan tantangan serius bagi pengelola perguruan tinggi.

Pasal 1 Permenristekdikti Nomor 44 Tahun 2015 tentang Standar Nasional Pendidikan Tinggi (Menteri Riset Teknologi dan Pendidikan Tinggi Republik Indonesia, 2015) dijelaskan dosen adalah pendidik profesional dan ilmuwan dengan tugas utama mentransformasikan, mengembangkan, dan menyebarluaskan ilmu pengetahuan, teknologi, dan seni melalui pendidikan, penelitian, dan pengabdian kepada masyarakat. Penilaian kinerja dosen seharusnya mencakup kinerja dosen di bidang pendidikan, penelitian, dan pengabdian kepada masyarakat. Akan tetapi, pada kesempatan ini hanya diteliti kinerja dosen di bidang penelitian dan publikasi ilmiah karena kinerja dosen di bidang lainnya sudah dilakukan penelitian. Selain itu, menurut Hemmings \& Kay (2014) di beberapa negara, misal Australia, Selandia Baru, Inggris mengakui penelitian lebih penting daripada pembelajaran, dan pengabdian pada masyarakat. Hal ini diprtegas oleh Mugimu et al. (2013) yang mengatakan bahwa pembelajaran dan penelitian merupakan pilar utama dalam pendidikan tinggi.

Perbedaan utama antara guru dan dosen adalah penelitian dan publikasi ilmiah. Dosen berkewajiban melakukan penelitian dan menerbitkan karya ilmiah, sedangkan 
guru tidak. Penelitian yang dilakukan dosen dapat berhasil dengan baik manakala ada dana yang mencukupi, beban tidak terlalu berat, dan ada kemauan bekerja yang tinggi. Hal ini selaras dengan hasil penelitian Mugimu et al. (2013) yang menunjukkan bahwa pendanaan yang tidak memadai, beban kerja yang berat, dan motivasi yang buruk menjadi kendala utama bagi keberhasilan penelitian mereka. Sementara itu, menurut Rohmah, Huda, \& Kusmintardjo (2016) faktor pendukung strategi peningkatan kemampuan dosen dalam penulisan karya ilmiah itu ada lima. Kelima faktor itu adalah: (1) terdapat alokasi dana untuk pelaksanaan pelatihan, (2) terdapat alokasi dana penelitian dan pengabdian masyarakat, (3) adanya usaha penambahan fasilitas publikasi jurnal ber-ISBN, (4) adanya alokasi dana untuk pemberian insentif sebagai penghargaan kepada dosen yang berprestasi dalam menghasilkan karya ilmiah, serta (5) adanya keaktifan dosen dalam mengikuti forum ilmiah.

Begitu pentingnya penelitian yang dilanjutkan dengan publikasi ilmiah, maka Pemerintah mewajibkan dosen untuk melakukan kedua hal tersebut dan telah diatur dalam Peraturan Menteri Penertiban Aparatur Negara dan Reformasi Birokrasi Nomor 17 tahun 2013 tentang Jabatan Fungsional Dosen dan Angka Kreditnya (Menteri Pendayagunaan Aparatur Negara dan Reformasi Birokrasi, 2013). Dalam Permen PAN \& RB tersebut dosen yang ingin memperoleh jabatan akademik Asisten Ahli, atau kenaikan jabatan dari Asisten Ahli ke Lektor, atau dari Lektor Kepala harus memiliki publikasi ilmiah. Untuk dosen yang memiliki jabatan akademik Asisten Ahli dan Lektor, penanganan pengelolalan karir jabatan akademiknya diserahkan kewenangannya kepada Perguruan Tinggi Negeri (PTN) untuk dosen di PTN kepada Koordinator Perguruan Tinggi Swasta (Kopertis)/ Lembaga Layanan Pendidikan Tinggi untuk dosen perguruan tinggi swasta (PTS).

Permenristekdikti Nomor 20 Tahun

2017 (Menteri Riset Teknologi dan Pendidikan Tinggi Republik Indonesia, 2017) yang mewajibkan publikasi untuk Lektor
Kepala dan Profesor adalah dalam rangka mendorong peningkatan kuantitas dan kualitas publikasi ilmiah pada tingkat nasional dan internasional. Meningkatnya jumlah publikasi pada jurnal internasional dan jurnal internasional bereputasi akan mendorong Indonesia mampu bersaing dengan bangsa-bangsa lain. Pada saat ini jumlah publikasi internasional Indonesia masih berada di bawah publikasi negaranegara maju, bahkan juga berada di bawah Malaysia dan Singapura.

Dikeluarkannya Permenristekdikti Nomor 20 Tahun 2017 adalah dengan tujuan untuk: (1) mendorong dosen yang sudah berada pada jenjang jabatan akademik Lektor Kepala dan Profesor untuk melaksanakan tugasnya sebagai pendidik profesional dan ilmuwan dengan melaksanakan tridarma perguruan tinggi secara sungguhsungguh, (2) mendorong Lektor Kepala dan Profesor untuk secara aktif dan produktif melakukan publikasi ilmiah di jurnal nasional terakreditasi, jurnal internasional, dan jurnal internasional bereputasi, dan (3) meningkatkan jumlah publikasi dosen dan ilmuwan Indonesia pada tingkat internasional sehingga mampu bersaing dengan publikasi bangsa-bangsa lain sejalan dengan Nawacita serta untuk memperoleh rekognisi internasional terhadap publikasi ilmiah ilmuwan Indonesia.

Sehubungan dengan uraian tersebut, maka penelitian ini hanya memfokuskan pada kinerja dosen di bidang penelitian dan publikasi ilmiah. Selaras dengan fokusnya, tujuan penelitian ini adalah untuk mengeksplor kinerja dosen di bidang penelitian dan publikasi ilmiah agar stakeholder dapat melakukan pembinaan terhadap kinerja dosen.

\section{Metode Penelitian}

Penelitian ini merupakan penelitian survei yang dilakukan pada bulan Maret sampai dengan Agustus 2018. Data dikumpulkan dengan teknik survei menggunakan kueisioner yang terdiri dari 20 butir yang setiap butirnya memiliki empat jawaban. Validitas isi instrumen dilakukan melalui 
expert judgments oleh 10 pakar dilanjutkan dengan analisis menggunakan formula Aiken. Hasil analisis menunjukkan bahwa semua butir dapat diterima karena koefisien validitas isi $(\mathrm{V})$ terkecil sebesar 0,736 , sedangkan menurut Aiken (1985) bila $\mathrm{n}=10$, $c=5$, dan $p=0,05$ diperoleh $V=0,730$. Sementara itu, reliabilitas instrumen diestimasi dengan formula Cronbach Alpha dan diperoleh $a=0,844$ (Retnowati, Mardapi, Kartowagiran, \& Suranto, 2017). Pengumpulan data dilengkapi dengan teknik observasi untuk mengecek kelengkapan dan kualitas dokumen.

Pada tahap awal, responden penelitian ini adalah 92 dosen Universitas Negeri Yogyakarta yang terdiri dari 22 Asisten ahli, 26 Lektor, 28 Lektor Kepala, dan 16 Profesor. Selanjutnya, hasil penelitian ini harus ditulis dalam jurnal ilmiah. Dosen yang memiliki jabatan akademik Lektor Kepala atau Profesor sebagai pembimbing mahasiswa program magister atau program doktor dalam menyusun karya ilmiah untuk dipublikasikan di jurnal nasional terakreditasi, jurnal internasional, atau jurnal internasional bereputasi, dan berkedudukan sebagai penulis pendamping atau penulis korespondensi, dapat menggunakan karya tulis tersebut untuk pemenuhan kewajiban memperoleh tunjangan profesi dan tunjangan kehormatan profesor. Dosen yang sudah dapat menunjukkan bukti penyerahan (submitted) artikelnya ke pengelola jurnal, namun belum diterbitkan, dapat dianggap sudah memenuhi syarat publikasi ilmiah di jurnal.

Data yang berhasil dikumpulkan untuk kinerja dosen di bidang penelitian sama dengan jumlah penelitian dikalikan bobotnya. Penelitian tingkat lokal diberi bobot 1 , penelitian tingkat nasional diberi bobot 2 , penelitian tingkat regional diberi bobot 3 , dan penelitian tingkat internasional diberi bobot 4 . Sebagai Ketua Tim peneliti diberi bobot 2 dan anggota Tim peneliti diberi bobot 1 . Sama halnya dengan penelitian, penulisan karya ilmiah juga diberi bobot. Artikel yang ditulis pada jurnal tingkat lokal diberi bobot 1 , jurnal tingkat nasional diberi bobot 2, jurnal internasional diberi bobot 3, dan jurnal internasional bereputasi diberi bobot 4. Penulis pertama/utama diberi bobot 2, sedangkan penulis kedua atau ketiga diberi bobot 1 .

Data yang dikumpulkan berbentuk skor, yakni banyaknya penelitian atau banyaknya artikel yang dihasilkan dikalikan dengan bobot. Skor yang diperoleh dideskripsikan kemudian dianalisis menggunakan teknik Kruskal Walls untuk mendeskripsikan ada atau tidak adanya perbedaan skor (jumlah penelitian dan/atau publikasi ilmiah $x$ bobot; artikel terbit di jurnal internasional bereputasi) antara Asisten Ahli, Lektor, Lektor Kepala, dan Guru Besar. Selanjutnya hasil analisis data kuantitatif ini diinterpretasikan dan dilengkapi dengan data kualitatif hasil wawancara dengan responden.

\section{Hasil Penelitian dan Pembahasan}

\section{Hasil Penelitian}

Penelitian ini merupakan penelitian survei dengan tujuan mendeskripsikan kinerja dosen dalam bidang penelitian dan publikasi ilmiah. Responden penelitian ini adalah 92 dosen UNY yang berasal dari tujuh fakultas, yakni Fakultas Teknik (FT), Fakultas Matematika dan Ilmu Pengetahuan Alam (FMIPA), Fakultas Ekonomi (FE), Fakultas Ilmu Sosial (FIS), Fakultas Ilmu Pendidikan (FIP), Fakultas Ilmu Keolahragaan (FIK), dan Fakultas Bahasa Sastra dan Seni (FBS). Dosen yang menjadi responden penelitian ini masing-masing fakultas terdiri dari Asisten Ahli, Lektor, Lektor Kepala, dan Guru Besar. Kinerja mereka di bidang penelitian dapat dilihat pada Gambar 1.

Gambar 1 menunjukkan bahwa ada kenaikan skor penelitian dari tahun 2015 ke tahun 2016, baik untuk dosen tingkat Asisten ahli, Lektor, Lektor Kepala, maupun Guru Besar. Sementara itu dari tahun 2016 ke tahun 2017 skor penelitian dosen relatif konstan, bahkan untuk dosen tingkat Guru Besar mengalami sedikit penurunan. Selanjutnya, deskripsi skor penelitian dosen pada tahun 2016 dan tahun 2017 dapat dilihat pada Tabel 1. 


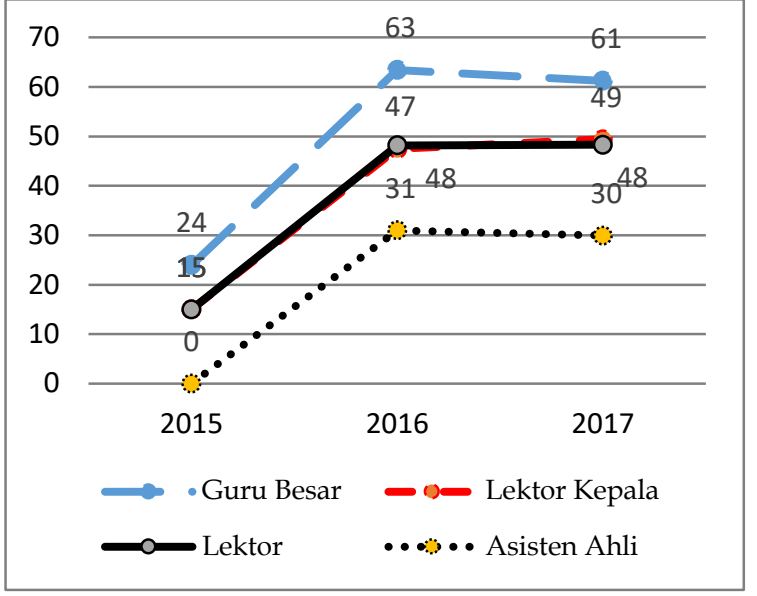

Gambar 1. Kinerja Dosen dalam Bidang Penelitian

Tabel 1. Deskripsi Skor Penelitian Dosen Tahun 2016 dan 2017

\begin{tabular}{lrcccc}
\hline \multirow{2}{*}{ Ket } & \multirow{2}{*}{ Jml } & \multicolumn{2}{c}{ Penelitian 2016 } & \multicolumn{2}{c}{ Penelitian 2017 } \\
& & Mean & Std. Dev. & Mean & Std. Dev. \\
\hline Guru Besar & 16 & 63.44 & 2.60 & 61.25 & 1.12 \\
Lektor Kepala & 28 & 47.46 & 2.25 & 49.41 & 1.96 \\
Lektor & 26 & 48.17 & 2.02 & 48.31 & 1.98 \\
Asisten Ahli & 22 & 30.98 & 1.12 & 29.93 & 1.74 \\
Total & 92 & & & & \\
\hline
\end{tabular}

Tabel 1 menunjukkan bahwa dari tahun 2016 ke tahun 2017, selain skor penelitian dosen meningkat ternyata standar deviasi atau varian skornya cenderung menurun kecuali dosen dengan jabatan Asisten Ahli. Hal ini dikarenakan kesempatan dosen dengan tingkat Asisten Ahli untuk melakukan penelitian tingkat nasional dan/ atau tingkat internasional sangat kecil, sedangkan penelitian jenis itulah yang memiliki bobot tinggi. Varian skor penelitian dosen dengan jabatan Asisten Ahli, baik tahun 2016 maupun tahun 2017 lebih kecil bila dibandingkan dengan varian skor lainnya, tetapi tahun 2017 lebih besar dari tahun 2016. Ini berarti bahwa sudah ada dosen dengan jabatan Asisten Ahli yang ikut penelitian dosen yang jabatannya lebih tinggi.

Untuk mengetahui apakah perbedaan skor penelitian antara dosen dengan jabatan Asisten Ahli, Lektor, Lektor Kepala, dan Guru Besar (Profesor) itu signifikan atau tidak dapat digunakan Teknik Kruskal Walls Test. Hasil analisis data dengan teknik Kruskal Wallis dapat dilihat pada Tabel 2.
Tabel 2. Hasil Uji beda dengan Teknik Kruskal Wallis

\begin{tabular}{lcc}
\hline & 2016 & 2017 \\
\hline Chi-Square & 14.60 & 14.15 \\
Df & 3 & 3 \\
Asymp.Sig & 0.002 & 0.003 \\
\hline
\end{tabular}

Tabel 2 menunjukkan bahwa ternyata ada perbedaan skor penelitian yang signifikan antara dosen dengan jabatan Asisten Ahli, Lektor, Lektor Kepala, dan Guru Besar (Profesor), baik untuk tahun 2016 maupun tahun 2017. Tahun 2016 dengan Chi-Square 14,599, df $=3$, dan $\mathrm{p}=0,002$, sedangkan tahun 2017, Chi-Square 14,146, df = 3, dan p $=0,003$. Skor penelitian terkecil dimiliki oleh dosen dengan jabatan Asisten Ahli dan semakin tinggi jabatan dosen, semakin tinggi pula skor penelitiannya.

Luaran penelitian adalah publikasi ilmiah, semakin tinggi tingkat penelitian (misal penelitian tingkat nasional), semakin tinggi pula tuntutan luarannya, mulai dari artikel yang dimuat di jurnal nasional tidak terakreditasi sampai pada artikel yang dimuat di jurnal internasional bereputasi (paling tidak terindeks Scopus Q3). Kinerja dosen pada bidang publikasi ilmiah dapat dilihat pada Gambar 2.

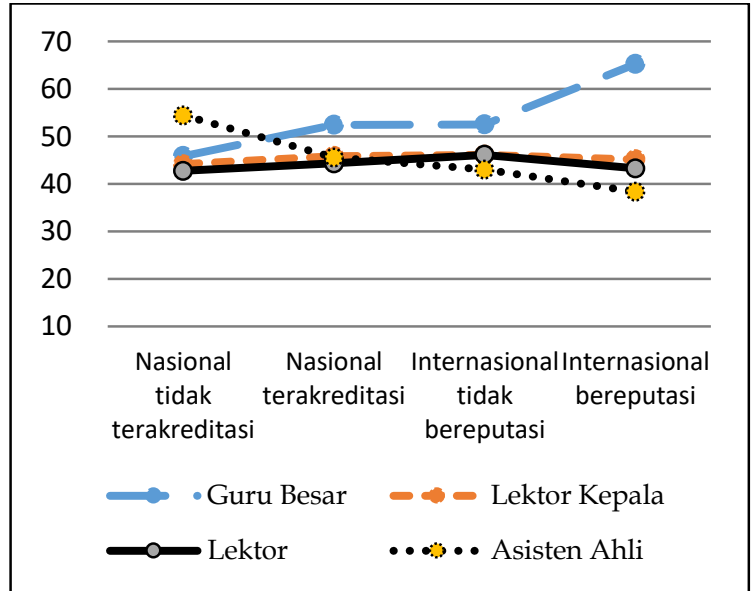

Gambar 2. Kinerja Dosen dalam Bidang Publikasi

Gambar 2 menunjukkan bahwa tidak ada perbedaan skor publikasi antara dosen jabatan Asisten Ahli, Lektor, Lektor Kepala, dan Guru Besar; ke empat jenis garis itu cenderung sama mendatar. Lain halnya 
pada jurnal internasional bereputasi, skor publikasi Guru Besar menanjak pesat. Deskripsi skor publikasi dosen dapat dilihat pada Tabel 3. Hal ini dipertegas dengan hasil analisis uji-beda menggunakan Kruskall Walls Test yang dapat dilihat pada Tabel 4.

Tabel 3. Deskripsi Skor Kinerja Dosen dalam Bidang Publikasi

\begin{tabular}{lccccc}
\hline \multirow{2}{*}{ Ket } & \multirow{2}{*}{ Jml } & \multicolumn{4}{c}{ Rerata skor publikasi } \\
& & A & B & C & D \\
\hline Guru Besar & 16 & 45.84 & 52.44 & 52.53 & 65.25 \\
Lektor Kepala & 28 & 44.14 & 45.86 & 46.13 & 45.16 \\
Lektor & 26 & 42.73 & 44.33 & 46.13 & 43.29 \\
Asisten Ahli & 22 & 54.43 & 45.57 & 43.02 & 38.36 \\
Total & 92 & & & & \\
\hline
\end{tabular}

Tabel 4. Hasil Uji beda dengan Teknik Kruskal Wallis

\begin{tabular}{lcccc}
\hline & \multicolumn{4}{c}{ Jenis publikasi } \\
& $\mathrm{A}$ & $\mathrm{B}$ & $\mathrm{C}$ & $\mathrm{D}$ \\
\hline Chi-Square & 3.26 & 2.11 & 3.77 & 19.98 \\
Df & 3 & 3 & 3 & 3 \\
Asymp. Sig & .360 & .551 & .286 & .000 \\
\hline
\end{tabular}

Keterangan:

$\mathrm{A}=$ Nasional tidak terakreditasi

$\mathrm{B}=$ Nasioanal terakreditasi

$\mathrm{C}=$ Internasional tidak bereputasi

$\mathrm{D}=$ Internasional bereputasi

Tabel 4 menunjukkan bahwa tidak ada perbedaan skor publikasi ilmiah pada jurnal nasional tidak terakreditasi, jurnal nasional terakreditasi, jurnal internasional antara dosen dengan jabatan Asisten Ahli, Lektor, Lektor Kepala, dan Guru Besar. Tabel tersebut juga menunjukkan bahwa ada perbedaan skor publikasi ilmiah pada jurnal internasional bereputasi antara dosen dengan Asisten Ahli, Lektor, Lektor Kepala, dan Guru Besar; Guru Besar memiliki skor tertinggi.

\section{Pembahasan}

Hasil penelitian menunjukkan bahwa dosen dengan jabatan paling rendah memiliki skor penelitian paling rendah. Hal ini dikarenakan pengalaman mereka masih rendah. Menurut Hemmings \& Kay (2014) pengalaman dapat mempengaruhi kinerja dosen dalam bidang penelitian. Lebih jauh Hemming dan Kay menjelaskan bahwa dosen muda yang berarti kurang berpengalaman juga akan merasa kebingungan untuk membagi waktu melaksanakan tugas di bidang penelitian, pembelajaran, dan pengabdian pada masyarakat. Oleh karenanya Hemming dan Kay menyarankan agar dosen kelompok ini aktif mengikuti pelatihan dan/atau magang ke peneliti senior.

Terkait dengan kemampuan dosen melakukan penelitian ini, Hutchinson \& Lovell (2004) menegaskan bahwa kualitas penelitian seorang dosen dipengaruhi oleh jenis pelatihan yang diterima. Lebih jauh Hutchinson dan Lovell (2004) mengatakan bahwa semakin baik pelatih itu memberikan motivasi dan pemahaman tentang penelitian dan berbagai metodologi penelitian, semakin tinggi kemampuan dosen terlatih pada bidang penelitian. Sayangnya, kemampuan ini berhenti pada saat pelatihan selesai, mereka tidak mampu menerapkan keahliannya itu setelah mereka kembali ke tempat kerja. Hal ini selaras dengan hasil penelitian Mugimu et al. (2013) yang dilakukan di Makerere University (MU). Penelitian ini menunjukkan bahwa pada awalnya para peserta pelatihan itu yakin akan kemampuannya melakukan penelitian, namun setelah kembali ke tempat kerja dengan beban mengajar yang berat, dana kurang memadai, dan sistem remunerasi yang buruk menyebabkan mereka kurang semangat (kurang termotivasi) melakukan penelitian. Menurut Stella (2008), motivasi itu penting, bahkan orang yang memiliki pengetahuan, keterampilan, dan kemampuan akan berkinerja buruk jika mereka tidak termotivasi. Ketika pekerja kekurangan motivasi mereka cenderung menggunakan antikerja perilaku seperti ketidakhadiran, kelalaian tugas, keterlambatan, kegagalan untuk memenuhi tenggat waktu, tampilan frustrasi terbuka dan semua faktor ini bekerja negatif untuk kinerja dan kredibilitas suatu organisasi.

Adanya perbedaan skor penelitian antara dosen dengan jabatan Asisten Ahli, Lektor, Lektor Kepala, dan Guru Besar; 
Guru Besar memiliki skor tertinggi adalah wajar. Hal ini dikarenakan dosen dengan jabatan rendah hanya sedikit memiliki akses untuk melakukan penelitian pada tingkat nasional dan/atau internasional, sedangkan penelitian dengan tingkat nasional dan internasional memiliki skor penelitian tinggi.

Bila diperhatikan Gambar 1 maka akan tampak garis skor penelitian dosen dengan jabatan Lektor hampir berimpit dengan garis skor penelitian dosen dengan jabatan Lektor Kepala. Ini berarti bahwa sudah ada kerjasama antara dosen dengan jabatan Lektor dan dosen dengan jabatan Lektor Kepala. Hasil penelitian ini memberikan inspirasi bahwa perlunya keterlibatan lebih jauh dari fihak universitas, misal selain melibatkan mahasiswa, dosen senior yang berjabatan Guru Besar juga harus melibatkan dosen yang berjabatan Asisten Ahli. Hal ini selaras dengan pendapat Ford (1992) yang menyatakan bahwa Fakultas harus memfasilitasi para dosen agar mereka tidak kehilangan motivasi untuk melakukan penelitian. Bahkan harus dipayakan agar di fakultas timbul budaya meneliti walaupun dengan berbagai kendala.

Salah satu luaran penelitian adalah publikasi ilmiah dan kinerja dosen dalam bidang publikasi ilmiah dapat dilihat pada Gambar 2. Gambar ini menunjukkan bahwa kinerja dosen dengan jabatan Asisten Ahli, Lektor, Lektor Kepala, dan Guru Besar dalam menulis artikel pada jurnal nasional tidak terakreditasi, jurnal nasional terakreditasi, dan jurnal internasional mendekati sama. Bahkan dosen dengan jabatan Asisten Ahli memiliki skor publikasi ilmiah yang lebih tinggi dari pada skor publikasi ilmiah Guru Besar. Hal ini wajar karena dosen dengan jabatan Guru Besar jarang sekali menulis artikel yang termuat dalam jurnal nasional tidak terakreditasi, atau hanya menjadi penulis kedua, sedangkan penulis pertamanya adalah dosen dengan jabatan Asisten Ahli.

Berbeda dengan artikel yang dimuat di jurnal internasional terindeks, skor publikasi ilmiah dosen dengan jabatan Guru Besar meningkat tajam. Guru Besar yang biasanya menjadi promotor dan/atau kopromotor mahasiswa program doktor yang juga memiliki kewajiban untuk melakukan publikasi ilmiah pada jurnal internasional terindeks. Mahasiswa program doktor harus melakukan publikasi ilmiah pada jurnal internasional terindeks sebagai penulis pertama, sedangkan promotor dan/atau kopromotornya sebagai penulis kedua atau ketiga.

Sementara itu, Tabel ini memaparkan bahwa tidak ada perbedaan skor publikasi ilmiah antara dosen dengan jabatan Asisten Ahli, Lektor, Lektor Kepala, dan Guru Besar, baik pada jurnal nasional tidak terakreditasi, jurnal nasional terakreditasi, dan jurnal internasional. Tabel 2 juga menunjukkan bahwa ada perbedaan skor publikasi ilmiah pada jurnal internasional terindeks antara dosen dengan jabatan Asisten Ahli, Lektor, Lektor Kepala, dan Guru Besar; dosen dengan jabatan Guru Besar memiliki skor tertinggi.

Bila dicermati dengan seksama ternyata skor kinerja dosen di bidang penelitian dan publikasi ilmiah masih rendah, masing-masing hanya mencapai skor 40 dan 45 dari skor maksimum 80 . Kinerja dosen di bidang penelitian dan publikasi ilmiah masih memerlukan perbaikan, dan salah satu cara yang dapat dilakukan adalah memotivasi dan memfasilitasi dosen. Hasil penelitian (Rohmah et al., 2016) menunjukkan bahwa strategi yang dapat dilakukan untuk memperbaiki kinerja dosen di bidang penelitian dan publikasi ilmiah adalah: (1) menyelenggarakan pelatihan, (2) mengalokasikan dana untuk melakukan penelitian dan publikasi ilmiah, (3) memfasilitasi jurnal, (4) memberikan insentif bagi dosen yang berhasil menulis di jurnal internasional terindeks, dan (5) membentuk Forum Ilmiah Dosen.

Senada dengan Rohmah et al. (2016), Hemmings \& Hill (2009) menyatakan bahwa untuk meningkatkan kinerja dosen di bidang penelitian dan publikasi ilmiah dapat dilakukan oleh pimpinan universitas dengan cara: (1) menyediakan waktu dan kesempatan yang cukup untuk memikirkan, dan mengeluarkan ide-ide dengan 
peneliti dan kelompok peneliti individual lainnya, (2) memberikan dukungan sistematis melalui program pembinaan dan pendampingan, (3) mengakses forum penelitian dan mendorong kehadiran di konferensi yang berorientasi pada penelitian, (4) menyesuaikan pelatihan penelitian dengan kebutuhan peneliti perorangan dan dengan demikian memastikan keragaman teknik dan metode penelitian yang lebih baru, (5) mengurangi efek dari kekuatan luar yang mengalihkan perhatian dari usaha penelitian, dan (6) merekrut, mengembangkan, dan mempertahankan dosen-dosen yang mampu melakukan penelitian berkualitas tinggi.

Sementara itu Sukirno (2017) dalam penelitiannya di beberapa perguruan tinggi negeri dan swasta yang ada di Indonesia menemukan bahwa sistem penghargaan yang lebih tinggi, komitmen dosen dan kepuasan dosen secara signifikan meningkatkan kinerja dosen di institusi pendidikan tinggi. Komitmen dosen memberikan dampak yang paling dominan pada kinerja dosen. Karyawan yang berkomitmen akan senang untuk tetap bersama dan melanjutkan layanan mereka ke organisasi, percaya pada nilai-nilai organisasi dan bekerja lebih baik untuk organisasi. Di bagian lain, Sukirno (2017) menjelaskan implikasi dari temuan penelitian ini terhadap praktik pendidikan tinggi di Indonesia, yakni imbalan finansial yang lebih baik dan imbalan non-finansial dapat menjadi pendekatan yang baik untuk meningkatkan kepuasan dosen.

Lebih jauh Sukirno (2017) menjelaskan bahwa sistem penghargaan yang baik memiliki dampak positif dan signifikan terhadap loyalitas karyawan terhadap organisasinya. Variasi hadiah akan mewakili volatilitas komitmen karyawan. Komitmen karyawan terhadap organisasi diwakili oleh perilaku mereka. Penelitian ini memberikan bukti bahwa penerapan sistem penghargaan yang lebih baik akan meningkatkan komitmen dosen di perguruan tinggi di Indonesia. Bahkan Idowu (Sukirno, 2017) menegaskan bahwa sistem hadiah berpengaruh positif terhadap kinerja karyawan di orga- nisasi mana pun, terutama di negara berkembang.

\section{Simpulan}

Berdasarkan hasil penelitian dan pembahasan maka dapat disimpulkan empat hal utama. Pertama, selama tiga tahun terakhir ada kecenderungan peningkatan skor penelitian dan skor publikasi ilmiah bagi dosen di semua kelompok jabatan. Kedua, ada perbedaan skor penelitian dilihat dari jabatan dosen, baik di tahun 2016 maupun tahun 2017. Ketiga, tidak ada perbedaan skor publikasi ilmiah pada jurnal nasional tidak terakreditasi, jurnal nasional terakreditasi, dan jurnal internasional, tetapi ada perbedaan skor publikasi internasional terindek dilihat dari jabatan dosen. Dosen dengan jabatan Guru Besar menduduki skor tertinggi, baik untuk penelitian maupun publikasi ilmiah diikuti oleh Lektor Kepala, Lektor, dan Asisten Ahli. Keempat, kinerja dosen di bidang penelitian dan publikasi ilmiah masih termasuk katagori sedang dan masih dapat ditingkatkan.

Saran yang dapat disampaikan dari penelitian ini yakni peningkatan kinerja dosen di bidang penelitian dan publikasi ilmiah dapat dilakukan dengan berbagai cara, beberapa di antaranya adalah sebagai berikut. Pertama, Pimpinan universitas dapat: (a) memberikan reward bagi dosen yang berhasil melakukan publikasi ilmiah internasional terindeks, (b) memberikan pelatihan tentang metodologi penelitian dan/atau cara menulis artikel yang layak dipublikasikan di jurnal internasional terindeks, (c) dan mefasilitasi kelompok dosen yang berinisiatif melakukan pelatihan secara mandiri. Kedua, Pimpinan universitas dapat merekrut, mengembangkan, dan mempertahankan dosen yang mampu melakukan penelitian yang berkualitas tinggi.

\section{Daftar Pustaka}

Abrami, P. C., Bernard, R. M., Borokhovski, E., Wade, A., Surkes, M. A., Tamim, R., \& Zhang, D. (2008). Instructional interventions affecting critical thinking skills and dispositions: a 
stage 1 meta-analysis. Review of Educational Research, 78(4), 1102-1134. https://doi.org/10.3102/00346543083 26084

Aiken, L. R. (1985). Three Coefficients for Analyzing the Reliability and Validity of Ratings. Educational and Psychological Measurement, 45(1), 131142.

https:// doi.org/10.1177/00131644854 51012

Astuti, A. D. (2017). Pengaruh motivasi dan disiplin kerja terhadap kinerja guru SD di Kabupaten Cilacap. Jurnal Akuntabilitas Manajemen Pendidikan, 5(2), 150.

https:// doi.org/10.21831/amp.v5i2.1 3931

Bai, S., Rajput, Q., Hussain, S., \& Khoja, S. A. (2014). Faculty performance evaluation system: An ontological approach. In 2014 IEEE/ACS 11th International Conference on Computer Systems and Applications (AICCSA) (pp. 117-124). IEEE. https:// doi.org/10.1109/AICCSA.201 4.7073187

Barber, M., \& Mourshed, M. (2012). Profesional development international. New York: Pearson.

Berk, R. A. (Ed.). (1986). Performance assessment. Baltimore: The Johns Hopkins University Press.

Chia, S. Y. (2013). The ASEAN economic community: progress, challenges, and prospects. Tokyo: Asian Development Bank Institute. Retrieved from https://www.adb.org/publications/a sean-economic-community-progresschallenges-and-prospects

Cronbach, L. J. (1985). Essential of psychological testing. New York: Harper and Ross.

Ford, M. E. (1992). Motivating humans goals, emotions, and personal agency beliefs. Newburry, California: SAGE Publications, Inc.
Hemmings, B., \& Hill, D. (2009). The development of lecturer research expertise: Towards a unifying model. Issues in Educational Research, 19(1).

Hemmings, B., \& Kay, R. (2014). Lecturer self efficacy, research skills, and publication output. Sydney: Charles Sturt University.

Hutchinson, S. R., \& Lovell, C. D. (2004). A Review of methodological characteristics of research published in key journals in higher education: implications for graduate research training. Research in Higher Education, 45(4), 383-403.

https:// doi.org/10.1023/B:RIHE.0000 027392.94172.d2

Jones, J., Jenkin, M., \& Lord, S. (2006). Developing effective teacher performance. California: SAGE Publishing Company.

Marzano, R. J., Frontier, T., \& Livingston, D. (2011). Effective supervision: supporting the art and science of teaching. Alexandria: ASCD.

Menteri Pendayagunaan Aparatur Negara dan Reformasi Birokrasi. Peraturan Menteri Pendayagunaan Aparatur Negara dan Reformasi Birokrasi Nomor 17 Tahun 2013 tentang Jabatan Fungsional Dosen Dan Angka Kreditnya (2013).

Menteri Riset Teknologi dan Pendidikan Tinggi Republik Indonesia. Peraturan Menteri Riset, Teknologi, dan Pendidikan Tinggi Republik Indonesia Nomor 44 Tahun 2015 tentang Standar Nasional Pendidikan Tinggi (2015).

Menteri Riset Teknologi dan Pendidikan Tinggi Republik Indonesia. Peraturan Menteri Riset, Teknologi, dan Pendidikantinggi Republik Indonesia Nomor 20 Tahun 2017 tentang Pemberian Tunjangan Profesi Dosen dan Tunjangankehormatan Profesor (2017).

Mugimu, C. B., Nakabugo, M. G., \& 
Katunguka, E. R. (2013). Developing capacity for research and teaching in higher education: a case of Makerere University. World Journal of Education, 3(6).

https:// doi.org/10.5430/wje.v3n6p33

Peleyeju, J. O., \& Ojebiyi, O. A. (2013).

Lecturers' performance appraisal and total quality management of Public Universities in South-Western Nigeria. British Journal of Education, 1(2), 41-47. Retrieved from http://www.eajournals.org/journals/ british-journal-of-education-bje/vol-1issue-2-december-2013/lecturersperformance-appraisal-total-qualitymanagement-public-universitiessouth-western-nigeria/

Retnowati, T. H., Mardapi, D., Kartowagiran, B., \& Suranto, S. (2017). Model evaluasi kinerja dosen: pengembangan instrumen untuk mengevaluasi kinerja dosen. Jurnal Penelitian Dan Evaluasi Pendidikan, 21(2), 206. https:// doi.org/10.21831/pep.v21i2.1 6626
Rohmah, N., Huda, M., \& Kusmintardjo, K. (2016). Strategi peningkatan kemampuan dosen dalam penulisan karya ilmiah (studi multi kasus pada Unisda dan Staidra di Kabupaten Lamongan). Jurnal Pendidikan: Teori, Penelitian, Dan Pengembangan, 1(7). Retrieved from http://journal.um.ac.id/index.php/jp tpp/article/view/6560

Stella, O. (2008). Motivation and work performance. Thesis. Unpublished. Master of Arts ini Human Resource and Employment of Institut of Sosial Studies. The Hague: ISS.

Sukirno. (2017). Modeling academic professional performance in higher education. International Journal of Environmental and Science Education IJESE, 12(8). Retrieved from http://www.ijese.net/makale/1933

Yen, W. M. (1993). Scaling performance assessments: strategies for managing local item dependence. Journal of Educational Measurement, 30(3), 187213. https://doi.org/10.1111/j.17453984.1993.tb00423.x 